\title{
Elements from in Vitro studies that help understand the action of heparins
}

Citation for published version (APA):

Hemker, H. C., Bendetowicz, A. V., \& Beguin, S. (1991). Elements from in Vitro studies that help understand the action of heparins. Thrombosis Research, 61(2), 1-10. https://doi.org/10.1016/00493848(91)90398-G

Document status and date:

Published: 01/01/1991

DOI:

10.1016/0049-3848(91)90398-G

Document Version:

Publisher's PDF, also known as Version of record

\section{Please check the document version of this publication:}

- A submitted manuscript is the version of the article upon submission and before peer-review. There can be important differences between the submitted version and the official published version of record.

People interested in the research are advised to contact the author for the final version of the publication, or visit the DOI to the publisher's website.

- The final author version and the galley proof are versions of the publication after peer review.

- The final published version features the final layout of the paper including the volume, issue and page numbers.

Link to publication

\footnotetext{
General rights rights.

- You may freely distribute the URL identifying the publication in the public portal. please follow below link for the End User Agreement:

www.umlib.nl/taverne-license

Take down policy

If you believe that this document breaches copyright please contact us at:

repository@maastrichtuniversity.nl

providing details and we will investigate your claim.
}

Copyright and moral rights for the publications made accessible in the public portal are retained by the authors and/or other copyright owners and it is a condition of accessing publications that users recognise and abide by the legal requirements associated with these

- Users may download and print one copy of any publication from the public portal for the purpose of private study or research.

- You may not further distribute the material or use it for any profit-making activity or commercial gain

If the publication is distributed under the terms of Article $25 \mathrm{fa}$ of the Dutch Copyright Act, indicated by the "Taverne" license above, 


\title{
ELEMENTS FROM IN VITRO STUDIES TIIAT HELP UNDERSTAND
} THE ACTION OF HEPARINS

\begin{abstract}
H.C. Hemker, A.V. Bendetowicz, S. Béguin.
Department of Biochemistry, University of Limburg, P.O. Box 616, 6200 MD Maastricht, The Netherlands.

\section{ABSTRACT}

In determining heparin one has the choise to test a specific activity, such as the decay constant of thrombin or factor Xa on a global test such as the aPTT. The best test would be a global test that directly reflects the only important global effect, to wit antithrombotic efficiency. Such a test does not yet exist. We propose that the thrombin potential, i.e. the time concentration integral of thrombin activity appearing in plasma after triggering is a plausible candidate for such a test.
\end{abstract}

There are two possible approaches to the study of antithrombotic drugs in general, and to the study of LMW heparins in particular. The most direct is to investigate their efficacy in animal models, or, even better, in patients. This leads to an immediate answer to the most important question: does it work? If it does, as is undoubtedly the case with LMWH, then we are left with the question of why. Here answers at different levels of sophistication are possible, that, in the end, will show us what the actual relation is between the biochemical properties of a drug and the antithrombotic action. Aspirin is the prime example of a drug that was known for a long time while the mode of action still remained the subject of research.

Key words: (Where the concentrations are indicated as follows: $\mathrm{H}=$ heparin, $\mathrm{A}=\mathrm{AT}$ III, $\mathrm{C}=$ heparin - AT III complex, $\mathrm{P}=$ heparin binding protein and $\mathrm{B}=$ heparin bound to that protein). 
The second possible approach in finding antithrombotic drugs is to start from a working hypothesis on the mode of action, that leads to a model which allows testing. Then one can select new drugs on basis of their performance in that model and only afterwards test, in animals and humans, those that are working in vitro. Antibiotics e.g. are selected on their capacity to inhibit growth of microorganisms in vitro. This second approach carries more risks and is less direct than the first one. But it also is about a thousand times quicker and cheaper. All one needs is a good in vitro model.

Antithrombotic pharmacology has not been very lucky in defining its models up to the present. Platelet aggregation has been the top of the bill for 25 years, without resulting in a drug that was manifestely better than aspirin; aspirin not being superior to either heparin or oral anticoagulation.

It also has been conceived that the anti-factor Xa activity in plasma would be a good indicator of its antithrombotic power (1-3). We found, however, that inhibition of prothrombin conversion in the extrinsic system was hardly inhibited by both UFH and LMWH $(4,5)$. This makes it difficult to imagine how anti Xa action could be a measure of antithrombotic activity. This immediately led to the next question: If not this, what indeed could be the property of a LMWH that determines its efficacy in a patient? For the moment we have no watertight answer. Our in vitro studies do suggest a possible approach though.

\section{Specific and global activities}

In the first articles on low molecular weight heparins the "specific activity" was defined as the capacity of heparin to stimulate AT III mediated factor Xa inactivation and it was opposed to "anticoagulant activity" which was defined as the capacity to prolong clotting times such as the aPTT (2). Even though they will not have been meant to do so, these definitions automatically suggest that there exists a specific (antithrombotic?) action of heparin as opposed to a less relevant anticoagulant activity

In fact however there are specific effects on inactivation of each of the coagulation enzymes. They are specific in the sense that they affect one specific reaction of the overall event of coagulation, i.e.

$$
\text { thrombin (or F.Xa or etc.) + AT III ----------> inactive product. }
$$

The action of heparin on each of these reactions can be quantitated in the form of a specific constant, as will be discussed below. This gives a set of constants that defines the heparin as to its pattern of specific enzyme scavenging. There is no reason whatsoever to assume that any of these constants will directly indicate with the overall antithrombotic effect. The fact that penta- 
saccharide has zero action on thrombin and dermatan sulfate does not act on factor Xa already disproves any hypothesis in that direction.

In order to estimate what the combined effect of all the specific actions is, including their secondary effects on feedback activations etc, one will have to measure the final effect, i.e. thrombin generation. This has been thought to be assessed with global coagulation assays such as aPTT. The fact that neither pentasaccharide nor DS will influence this test very much, shows that the aPTT is not a good model (and neither is any other coagulation assay, for that matter). It is here that we propose the thrombin generation curve as an alternative.

\section{The specific decay constants}

Heparins increase the decay of clotting factors in plasma. This capacity is reflected in a decrease of the halflife time of the factor under study in a plasma containing heparin. Rather than $t_{1 / 2}$ we prefer to use the pseudo first order decay constant, $k_{d e c}$, that is proportional to the inverse of the halflife time. Its dimension is inverse time, usually $\mathrm{min}^{-1}$. Heparin activity, and therefore $k_{d e c}$, increases linearily with the amount of heparin added. The increase of $k_{d e c}$ per unit of weight of heparin therefore indicates how good a heparin is in catalyzing the decay of a clotting factor. The actual value is dependent upon the conditions of measurement (see below). It is important that $\mathbf{k}_{\mathbf{d e c}}$ should be measured under conditions as near as possible to those prevailing in the human in vivo. We should therefore define the specific decay constant of heparin for a specific factor, here thrombin, in the following way:

The thrombin related specific decay constant (IIa-SDC) of a heparin is the increase per $\mu \mathrm{g}$ of material of the pseudo first order breakdown constant of human thrombin in normal human plasma under conditions that are as near as possible to the physiological ones.

The SDC for other clotting factors can be defined analogously. Because the dimension of the breakdown constant is $\min ^{-1}$, the SDC has $\min ^{-1} \mu \mathrm{g}^{-1}$ as a dimension. The SDC can be expressed either per $\mu \mathrm{g}$ of total material or per $\mu \mathrm{g}$ of high affinity material (SDC(HAM)). Once the SDC has been defined there is no use to express the potency of a heparin in anti-Xa or antithrombin units any more. It is still usefull however to compare the activity of given preparation to that of a suitable standard, were it only to check the laboratory procedures.

\section{A global unit}

Much of the confusion in the field of heparins arises from the fact that we are repeatedly, and often even unconsciously, switching back and forth between the measuring of effects of heparin and interpretation of the importance of these effects. It therefore seems useful to define a unit of heparin that is independent of any mechanistic interpretation of the mode of action of heparin. Starting from the observation that heparins, like oral anticoagulation, hirudin, dermatan sulfate etc. etc., work by diminishing the amount of active thrombin that generates in 
clotting plasma, we define the $\mathrm{IC}_{50}$ unit as follows: One IC 50 unit of heparin is that amount of heparin that has to be added to $1 \mathrm{ml}$ of plasma in order to inhibit for 50\% the generation of thrombin in normal plasma.

It is interesting to note that it hardly seems to matter, as far as our experience goes, whether one measures the inhibition of the thrombin peak or the area under the thrombin generation curve. Yet there are practical reasons to prefer the area under the curve: We found that if the experimental conditions are kept constant the peak of the curve correlates perfectly with the surface, but the peak is subject to variation of thromboplastin concentration and the surface is not. Also the experimental error in determining the surface is smaller and it is possible to device a simple test that measures it directly.

As far as our experience goes the dose-effect relationship for heparins and the surface under the curve is linear on a log-log plot and parallel for different types of heparin.

\section{The relation between specific and global effects.}

Of course there is a direct relation between the ensemble of specific decay constants (IIa, $\mathrm{Xa}, \mathrm{IXa}$ ) and the global effect of a heparin. However direct, it is not necessarily linear or even simple. The anti-Xa action of a heparin for instance is not immediately reflected in inhibition of thrombin generation. This surprized at first, but appears a posteriori. to be quite logical as we will show now.

We recall that we developed a method to determine the course of prothrombinase activity in clotting plasma. The basic principle is that we determine the experimentally found velocity of change of thrombin concentration ( $\mathrm{vexp}_{\mathrm{ex}}$ ). Knowing the decay constant of thrombin in plasma we calculate the thrombin breakdown velocity $\left(v_{d e c}\right)\left(v_{d e c}=k_{d e c}[T]\right.$, where [T] represents the concentration of thrombin). The prothrombin conversion velocity then equals the experimental velocity plus the decay velocity $-\mathrm{dP} / \mathrm{dt}=\mathrm{v}_{\text {exp }}+\mathrm{k}_{\mathrm{dec}}[\mathrm{T}]$.

The decay constant of thrombin in plasma $\left(\mathbf{k}_{\mathbf{d e c}}\right)$ is determined in a separate experiment. For full details on the method see ref. 6 . With this method we showed that the course of extrinsically triggered prothrombin conversion under the influence of heparin was only marginally inhibited by heparin $(4,5)$. Most low molecular weight heparins did not or hardly inhibit prothrombinase activity either. In view to the relatively high anti- $X_{\mathbf{a}}$ action of LMWHs as compared to UFH this was an unexpected result. In view of the allegedly therapeutic importance of anti-factor $X_{a}$ action(s) it was even disturbing $(1,2)$. In the light of our knowledge of the physiology of prothrombin conversion, this result is readily explained however.

We showed as early as 1968 that the prothrombinase complex forms from its three components (factor $\mathrm{Xa}$, factor $\mathrm{Va}$ and phospholipid) by equilibrium reactions (7). This means that the amount of prothrombinase formed when two components are fixed and the third one varies, will show saturation kinetics. Later studies gave the reaction constants of prothrombin 
conversion (8). This allows us to calculate the molar concentration of prothrombinase complex in clotting plasma from the rate of prothrombin conversion. At the moment of maximum activity the velocity of prothrombin conversion is $\sim 200 \mathrm{nM} / \mathrm{min}$ (4). The phospholipid concentration is $\sim 1 \mu \mathrm{M}$ and the remaining concentration of prothrombin is about $1 \mu \mathrm{M}$. We know from ref. 8 that under these conditions $\mathrm{K}_{\mathrm{m}}=0.2 \mu \mathrm{M}$ and $\mathrm{k}_{\mathrm{cat}}=2000$.min. We also know that the system follows Michaelis-Menten kinetics, so that we can calculate the enzyme concentration from the formula $v=\left(k_{c a t} E . S.\right) /\left(K_{m}+S\right)$. In this way we find the prothrombinase concentration to be $0.3 \mathrm{nM}$. We further know that the prothrombinase activity is critically dependent upon the appearance of factor $\mathrm{Va},(9)$ and that the fraction Xa concentration has a peak value of around $10 \mathrm{nM}(10)$. It follows that the concentration of factor Va must be about $0.3 \mathrm{nM}$. Knowing that the $\mathrm{K}_{\mathrm{d}}$ of factor $\mathrm{Va}$ and factor $\mathrm{Xa}$ under these conditions is $0.3 \mathrm{nM}$ (11), one can calculate the relations between factor $X_{a}$ concentration and prothrombinase concentration (Fig.1). From this curve one can determine what the relation between inhibition of factor $\mathrm{X}_{\mathrm{a}}$ and prothrombin is (Fig. 2).

Fig. 1 The amount of prothrombinase as a function of factor Xa concentration. The amounts of the other reactants were taken to be: factor $V a: 0.3 \mu M$ and phospholipid $1 \mu \mathrm{M}$.

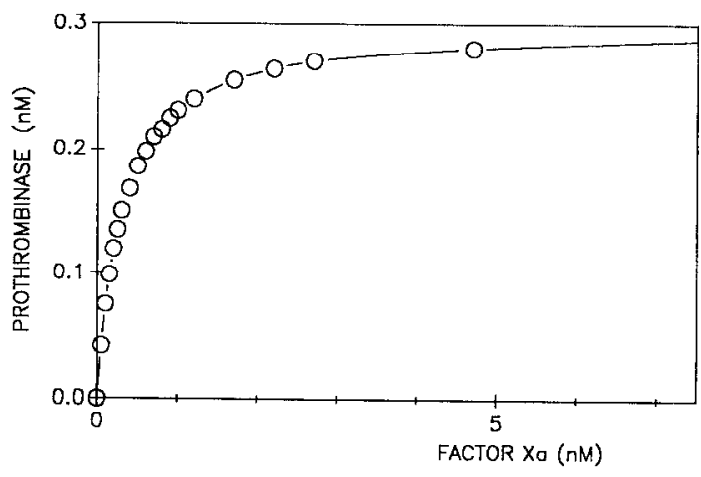

Fig. 2 The relation between factor Xa inhibition and orothrombinase inhibition. From the data of fig. 1 it is calculated how inhibition of factor $\mathrm{Xa}$ is reflected in inhibition of prothrombinase (o). Also are plotted $(\Delta)$ the inhibition of peak thrombin activity and of prothrombinase as observed in whole plasma (from ref. 4).

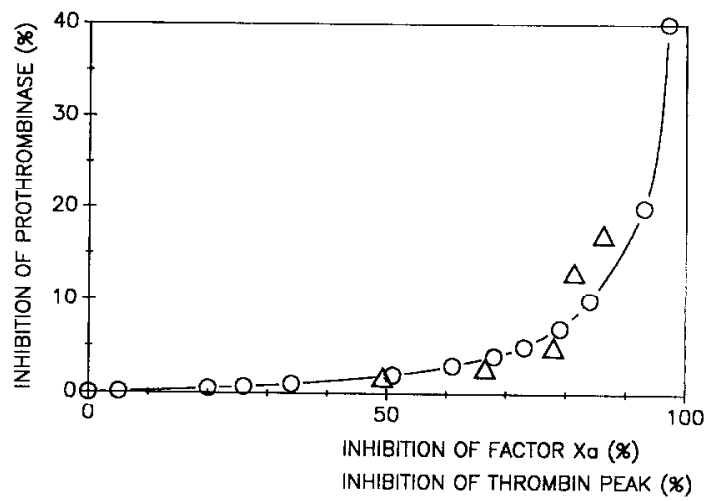


It appears that factor $\mathrm{X}_{\mathrm{a}}$ has to be inhibited $85 \%$ before prothrombinase inhibition will rise above $10 \%$. This general conclusion is largely independent on the actual numerical values of the kinetic constants, provided that they are of the order of magnitude indicated.

It thus appears that there is no discrepancy between the fact that heparins, especially LMWH, do increase the decay of factor $X_{a}$ in plasma, and the observation that this decay is hardly reflected in a decrease of the velocity of prothrombin conversion.

In Fig. 2 we also plotted (from ref. 4) the inhibition of prothrombinase against the inhibition of the thrombin peak. The inhibition of the thrombin peak we have shown to be directly proportional to the antithrombin activity in the plasma. The antithrombin activity itself is proportional to the anti Xa activity, or in the case of UFH even identical. Inhibition of the Xa activity therefore should be proportional to the inhibition of the thrombin peak but not to inhibition of prothrombinase. Figure 2 shows that this is indeed what has been found in clotting plasma. It thus seems that the calculations based on observations on the enzymatology of prothrombinase do apply to the situation in plasma.

\section{The importance of measuring under phusiological conditions.}

Recent work from our laboratory shows that the measuring of anti factor Xa and antithrombin activities according to the general practice of the clinical laboratory may be only remotely related to the actual decay of these factors in clotting human plasma (Lindhout, Béguin, unpublished). This will be discussed elsewhere. Here we want to focus on the action of heparin binding proteins in plasma.

Heparin binds reversibly to AT III. Half saturation is seen at $\sim 20 \mathrm{nM}$ of heparin. The heparin - AT III complex in a purified systems has a specific activity of about $200 \mathrm{~min}^{-1} \cdot \mathrm{U}^{-1}$. In plasma however, the heparin is partitioned between AT III and other heparin binding proteins such as histidin rich glycoprotein, vitronectin and others (10-20). The two relevant reactions are:

Heparin + antithrombin III $\rightarrow$ hep - AT III complex

Heparin + binding protein $\rightarrow$ complex without heparin activity

This situation is analogous to classical competitive enzyme inhibition with AT III in the role of substrate, the heparin binding protein in the role of inhibitor and heparin as the enzyme, so that in fair approximation: $\mathrm{C}=\mathrm{TA} / \mathrm{K}(1+(\mathrm{P} / \mathrm{M}))+\mathrm{A})$

The efficiency of the inhibitory effect of heparin binding proteins on heparin action is determined by the amount of protein $(\mathrm{P})$, and by the dissociation constant of the protein for the heparin (M) relative to the dissociation constant of AT III for heparin (K).

We define the "efficiency factor" $F=1+\mathrm{P} / \mathrm{M}$. This is the factor by which the actual heparin concentration in the plasma has to be devided in order to obtain the heparin concentration that 
would be equipotent if no heparin binding proteins other then AT III would be present. For the two most avid heparin binders (vitronectin and histidin rich glycoprotein) this factor to be 60 and 200 respectively. Heparin also interacts with albumin, fibrinogen, fibronectin and lipoproteins. It thus does not seem far fetched to estimate the complete effect as a 300-600 fold decrease of the efficacy of heparin as compared to a purified system. In the concentration range of antithrombin in clotting plasma (3-1 $\mu \mathrm{M})$ the fraction of heparin that is bound will be roughly proportional to the amount of AT III present as well as proportional to the amount of heparin added.

\section{The thrombin potential}

From the above paragraphs it will be clear that an acceptable in vitro model of antithrombotic potency should be a global test, encompassing the whole mechanism of coagulation and also a test carried out in a medium that is as near as possible to plasma.

In order to check whether any proposed test it is an acceptable candidate for a model, there should be no known antithrombotics that do not influence it. If we exclude Aspirin from the list, the claim for universality can be restricted to a large subclass of antithrombotics, i.e. the anticoagulants. As will be clear from the above we propose the thrombin potential, that is: the surface under the thrombin generation curve, as a possible parameter that reflects antithrombotic potency. The reason why we propose the surface is that we want an experimental value that is proportional to both the amount of thrombin and the duration of its action. Thrombin being an enzyme, its concentration as well as the the time during which it is active determine its effect. A simple method to estimate the concentration-time interval of thrombin - that we called the thrombin potential, will be published elsewhere. We found that the thrombin potential is diminished by oral anticoagulation, all heparins, hirudin, dermatan sulfate lactobionic acid and, in short, every anticoagulant that we tested.

Whether is a representative in vitro parameter of antithrombotic efficacy should follow from studies on its correlation in vivo inhibition of thrombosis.

\section{REFERENCES}

1. YIN, E.T., WESSLER, S., and STOLL, P.J. Identity of plasma-activated factor $X$ inhibitor with antithrombin III and heparin cofactor. J. Biol. Chem. 246, 3712-3719, 1971.

2. ANDERSSON, L-O., BARROWCLIFFE, T.W., HOLMER, E., JOHNSON, and E.A., SIMS, G.E.C. Anticoagulant properties of heparin fractionated by affinity chroma- 
tography on matrix-bound antithrombin III and by gel filtration. Thromb. Res. 9, 575$583,1976$.

3. CARTER, C.J., KELTON, J.G., HIRSH, J., CERSKUS, A., SANTOS, A.V., and GENT, M. The relationship between the hemorrhagic and antithrombotic properties of two low molecular weight heparins in plasma. Blood 59, 1239-1245, 1982.

4. BÉGUIN, S., LINDHOUT, T., and HEMKER, H.C. The mode of action of heparin in plasma. Thromb. Haemostas. 60, 457-462, 1988.

5. HEMKER, H.C. The action of heparin in plasma. XIth Congress on Thrombosis and Haemostasis 1987. Edited by M. Verstraete, J. Vermylen, H.R. Lijnen and J. Arnout. Leuven University Press, 17 - 36, 1987.

6. HEMKER, H.C., WILLEMS, G.M., and BÉGUIN, S. A computer assisted method to obtain the prothrombin activation velocity in whole plasma independent of thrombin decay processes. Thrombosis and Haemostasis 56, 9-17, 1986.

7. HEMKER, H.C., ESNOUF, M.P., HEMKER, P.W., STUART, A.C.W., and MACFARLANE, R.G. Formation of prothrombin converting activity. Nature 215, 248$251,1967$.

8. ROSING, J., TANS, G., GOVERS-RIEMSLAG, J.W.P., ZWAAL, R.F.A., HEMKER H.C. The role of phospholipids and factor Va in the prothrombin complex. J. Biol.Chem. 255, 274-283, 1980.

9. PIETERS, J., LINDHOUT, T., and HEMKER, H.C. In situ generated thrombin is the only enzyme that effectively activates factor VIII and factor V in the plasma. Blood 74, 1021-1024, 1989.

10. HEMKER, H.C., BÉGUIN, S., PIETERS, J., and LINDHOUT, T. The ex-vivo correlate of antithrombotic action of heparin. Ann. N.Y. Acad. Sci., 556, 146-157, 1989.

11. LINDHOUT, T., GOVERS-RIEMSLAG, J.W.P., WAART, v.d.. P., and HEMKER, H.C., ROSING, J. Factor Va- factor Xa interaction. Effects of phospholipid vesicles of varying composition. Biochem. 21, 5494-5502, 1982. 
12. CARDIN, A.D., HIROSE, N., BLANKENSHIP, D.T., and JACKSON R.L., HARMONY, J.A., SPARROW, D.A. Binding of a high reactive heparin to human apolipoprotein E: identification of two heparin-binding domains. Biochem. Biophys. Res. Commun. 134, 783-789, 1986.

13. KEESKES, E., BUKI, K.G., BAUER, P.I., MACHOVICH, R., and HORVATH, I. Interaction of heparin with lipoproteins. Role of the complex in the activation of thrombin and plasmin. Thromb. Haemost. 49, 138-141, 1983.

14. LANE, D.A. PEJLER, G., FLYNN, A.M., THOMPSON, E.A., and LINDAHL U. Neutralization of heparin related saccharides by histidin-rich glycoprotein and platelet factor 4. J. Biol. Chem. 261, 3980-3986, 1986.

15. LIJNEN, H.R., HOYLAERTS, M., and COLLEN D. Heparin binding properties of human histidin-rich glycoprotein. Mechanism and role in the neutralization of heparin in plasma. J. Biol. Chem. 258, 3803-3808, 1983.

16. LIJNEN, H.R., HOEF, VAN B., and COLLEN D. Histidin-rich glycoprotein modulates the anticoagulant activity of heparin in human plasma. Thromb. Haemost. 5I, 266-268, 1984.

17. MACGREGOR, I., LANE, D.A., and KAKKAR, V.V. The anti-heparin properties of human low-density lipoprotein. Biochem. Biopkys. Acta. 617, 472-479, 1980.

18. MCKAY E.J., and LAURELL C.B. The interaction of heparin with plasma protein. Demonstration of different binding site for antithrombin III complexes and antithrombin III. J.Lab.Clin.Med. 69-80, 1980.

19. NIWA, M., YAMAGISHI, R., KONDO, S., SAKURAGAWA, N., and KOIDE, T. Histidin-rich glycoprotein inhibits the antithrombin activity of heparin cofactor II in the presence of heparin of dermatan sulfate. Thromb. Res. 37, 237-240, 1985.

20. PETERSON, C.B., MORGAN, W.T., and BLACKBURN, M.N. Histidin-rich glycoprotein modulation of the anticoagulant activity of heparin. Evidence for a mechanism involving competition with both antithrombin and thrombin for heparin binding. The Journal of Biological Chemistry 262, 7567-7757, 1987. 
21. PREISSNER, K.T., and MULLER-BERGHAUS G. S. protein modulates the heparincatalyzed inhibition of thrombin by antithrombin III. Evidence for a direct interaction of Sprotein with heparin. Febs. Lett. 1985.

22. TOLLEFSEN, D.M., and PESTKA C.A. Modulation of heparin cofactor II activity by histidin-rich glycoprotein and platelet factor 4. J. Clin. Invest. 75, 496-501, 1985. 